\title{
ACID-BASE CHANGES IN YOUNG MEN AFTER ORAL INTAKE OF ETHANOL
}

\author{
Buchancova J. ${ }^{1}$, Murajda L. ${ }^{1}$, Buchanec J. ${ }^{2}$, Hudeckova H. ${ }^{1}$, Lukacova D. ${ }^{1}$, \\ Hrivnak $\mathrm{I}^{3}$
}

\begin{abstract}
${ }^{1}$ Department of Public Health, Jessenius Faculty of Medicine, Comenius University, Martin ${ }^{2}$ Clinic of Children and Adolescents, Jessenius Faculty of Medicine, Comenius University and University Hospital, Martin, Slovakia ${ }^{3}$ Health Spa Resort s.r.o., Dudince, Slovakia
\end{abstract}

\section{A b s t r a c t}

The authors studied a group of healthy men of an average age $24.4 \pm 2.1$ yrs ( \pm \pm SEM) before the oral intake of ethanol and 1 and 2 hours after its ingestion. The volunteers, $n=10$, of an average weight $79.1 \mathrm{~kg} \pm 2.7 \mathrm{~kg}( \pm \mathrm{SEM})$ consumed within one minute $0.42 \mathrm{~g}$ ethanol/ $\mathrm{kg}$ of individual body weight diluted in water (ratio 1:3). Concentrations of alcohol in venous blood were determined using Widmark method. One hour after the peroral intake the ethanol concentration reached $0.39 \pm 0.02 \mathrm{~g} / \mathrm{kg}, 2$ hours after peroral intake it was $0.33 \pm 0.03 \mathrm{~g} / \mathrm{kg}$.

Parameters of acid-base balance (ABB) from venous blood samples were monitored in probands. Compared with baseline values, the $\mathrm{pH}$ of blood did not change significantly. The values of $\mathrm{pCO}_{2}$ in blood were significantly decreased, even the values of actual $\mathrm{HCO}_{3}{ }^{-}$and standard $\mathrm{HCO}_{3}$. The decrease of base excess continued 2 hours after intake of ethanol. There were significant variations in $\mathrm{ABB}$ (paired $\mathrm{t}$ - test), however in tolerable range. The values of glycaemia, AST, ALT, GGT, and AMS before ethanol intake and 1 and 2 hours after intake of ethanol were in the reference range and they did not change significantly.

The authors find important to document even "small" intake of alcohol which may be the cause of ABB shift to a pathological range. The doctors should always keep this in mind when doing the diagnostic statement. The changes of $\mathrm{ABB}$ due to alcohol consumption must be expected, especially if they are associated with other pathological conditions affecting the ABB.

Key words: ethanol, venous blood, healthy young persons, acid-base balance, hypocapnia, glycaemia, AST, ALT, GMT, AMS

\section{INTRODUCTION}

Ethanol and its metabolic products affect homeostasis of the organism. Only a very small amount of consumed alcohol is excreted unchanged by the kidneys, lungs and skin. A high percentage (90 - 98\%) is degraded in the liver. Ethanol metabolism in the body is closely linked to its oxidation: first, the influence of a cytosolic enzyme alcohol dehydrogenase to acetaldehyde (only a small percentage by microsomal alcohol-oxidizing system, MEOS and catalase) and then there is the action of liver aldehyd dehydrogenase that creates acetic acid. Acetaldehyde is highly reactive substance that inhibits the catabolism of acetate in the Krebs cycle; it activates collagen synthesis and stimulates the formation of free oxygen radicals with subsequent lipoperoxidation (16). Acetaldehyde has the ability to bind to the nucleic acids and proteins in particular. Measuring its bound protein amount can be used as a marker for alcoholism, similarly as it is in pursuit of glycosylated hemoglobin in diabetics $(4,18)$. Acetaldehyde in connection with the free amino acids, especially lysine amino residues can form neoantigenes, which are then directed against the body's own proteins, especially against hepatocytes (16). The final metabolic products of ethanol removal in the body are carbon dioxide and water.

In the way of alcohol dehydrogenase, that forms $\mathrm{NADH}$ and acetaldehyde is the main way of degradation of ethanol in non-drinkers, who drank alcohol only occasionally (15). With rising incomes of alcohol after several weeks ethanol exposure does not increase the amount

Ad dress for correspond e n c e

Prof. MUDr. Janka Buchancova, CSc., Department of Public Health, Jessenius Faculty of Medicine, Sklabinska Str. N.26, 03601 Martin, Slovakia.

E-mail: buchancova@jfmed.uniba.sk 
of enzyme alcohol dehydrogenase. Supporting role in oxidation happening assumes inducible MEOS office system (known in the literature also as cytochrome P450-CYP2E1$11,14)$, which can increase their activity 2-3 times, but this is associated with greater demands for oxygen. This may gradually lead to the development of centrilobular necrosis and alcoholic liver cirrhosis (17). In the pathogenesis of alcoholic hepatitis is involved also endotoxin transfer from G-bacteria through the impaired intestinal wall into the circulation and binding to Kupffer cell receptor, which subsequently released mediator TNF-alpha which induces other inflammatory cytokines (11).

Ethanol may cause fluctuations in acid-base balance, which is strongly reflected particularly in cases of intoxication with higher doses, unfortunately, these cases currently often occur not only in adults, but also in children, adolescents and young subjects $(7,8)$. Alcohol intake increases concentration of $\mathrm{NADH}$ and the ratio of $\mathrm{NADH} / \mathrm{NAD}$. Higher concentrations of NADH inhibit the performance of Krebs cycle and $\beta$-oxidation of fatty acids in mitochondria, increase the lactate/pyruvate ratio and $\beta$-hydroxybutyrate/acetoacetate leading to the acidosis with formation of ketone, the inhibition of glycolysis and gluconeogenesis. In the renal tubules is increased resorption of uric acid, which may provoke the hyperuricemia and the gouty attack. Alcohol increases the concentration of catecholamines and through their effect also depletes glycogen reserves in the liver (15).

Monitoring the impact of peroral, less precisely quantified dose of ethanol on the parameters of acidosis and their following evaluation in relation to levels of ethanol found in the blood at defined periods of time, can provide a picture of early changes in acid-base balance $(\mathrm{ABB})$ and correction of the compensatory mechanisms of the organism.

Not least is not specifically estimated whether and to what extent, small doses of alcohol affect the acid-base. More precise knowledge of the situation - a possible shift in the acid-base parameters - would help to reveal whether doctors should consider in the diagnostic statement after blood collection to investigate $\mathrm{ABB}$, reflect that pathological values can also be caused by the summation of certain disease plus a small but already significant "ethanol background" when e.g. a history of the patient did not, sometimes intentionally, ingested of alcohol recently.

Therefore, the authors decided to assess the effect of peroral small doses of ethanol on acid-base balance in healthy persons in relation to the monitoring of blood ethanol concentrations. Evaluation of the selected parameters of circulation after peroral intake of alcohol has been the subject of our previous study (1).

\section{SUBJECTS AND METHODS}

Authors examined a group of healthy men of average age of $24.4 \pm 2.1$ years $(\mathrm{x} \pm \mathrm{SEM})$ before peroral ethanol intake and after its ingestion of 1 and 2 hours. Probands $(\mathrm{n}=10$, of average weight $79.1 \mathrm{~kg} \pm 2.7 \mathrm{~kg}$ ) consumed within 1 minute $0.42 \mathrm{~g}$ of ethanol $/ \mathrm{kg}$ body weight diluted with water in a ratio of 1:3. Alcohol concentrations in venous blood were studied before and after 1 and 2 hours after its intake by Widmark method (after disinfection of the sampling point with solution of hydrogen peroxide). In parallel in the same situations were assessed also parameters of $\mathrm{ABB}$, before and after 1 and 2 hours after drinking alcohol, in three samples of capillary blood from a finger pad (after friction, before taking the blood in order to improving arterialization). In all samples of venous blood were also determined: glycaemia, aspartate aminotransferase (AST), alanine aminotransferase (ALT), gamma glutamyl transferase (GMT) and total amylase (AMS). Investigated men after breakfast ( 2 rolls and tea or a glass of fruit juice, between 6-7 a.m.) passed the examination between 9.30 to $12.30 \mathrm{pm}$. During the examination they were sitting. During blood taking, they were lying for a short time.

Informed consent was obtained from all subjects under investigation. The results were processed by mathematical and statistical procedures, by calculating the average values and \pm SEM, using paired t-test. 


\section{RESULTS}

Figure 1 shows the average concentration of ethanol in venous blood before and after 1 and 2 hours after ingestion of ethanol. Mean value of blood ethanol was $0.10 \pm 0.03 \mathrm{~g} / \mathrm{kg}$, after 1 hour $0.39 \pm 0.02 \mathrm{~g} / \mathrm{kg}$ and after 2 hours $0.33 \pm 0.03 \mathrm{~g} / \mathrm{kg}$.

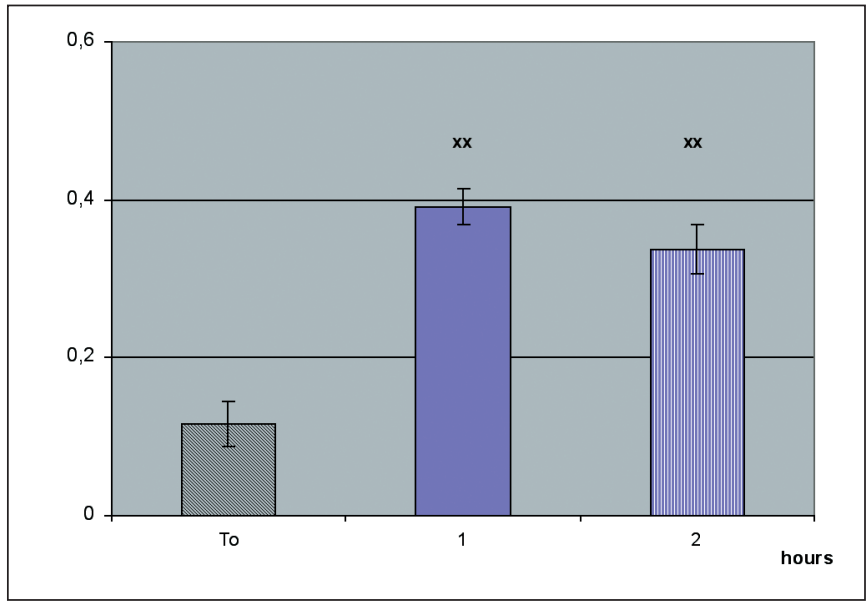

Fig.1 Average level of ethanol in venous blood before the ethanol ingestion, 1 hour after ingestion and 2 hours after ingestion. $\mathrm{xx} \mathrm{p}<0.01$ compared with To (To = initial time).

Fig. 2, 3 and 4 present ABB parameters before ingestion of ethanol and 1 and 2 hours after the ingestion. Figure 2a presents values of $\mathrm{pH}$ in the blood before and 1 and 2 hours after the ingestion of ethanol. We found that 1 hour after ingestion of ethanol the $\mathrm{pH}$ was 7.42. After 2 hours the $\mathrm{pH}$ in blood was 7.41 (NS).

a

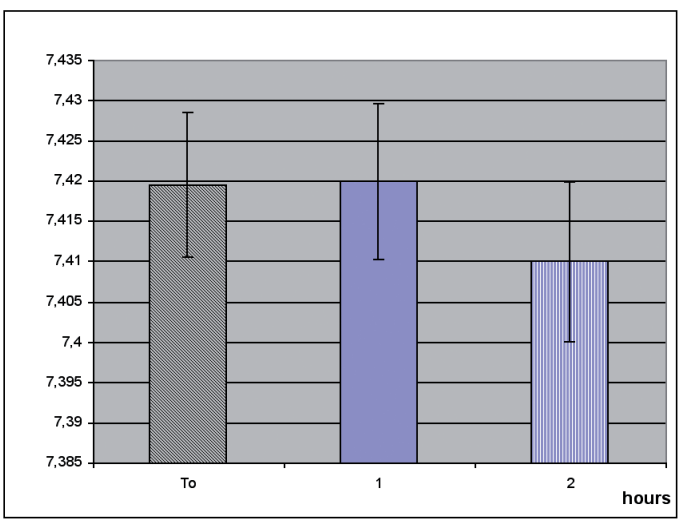

b

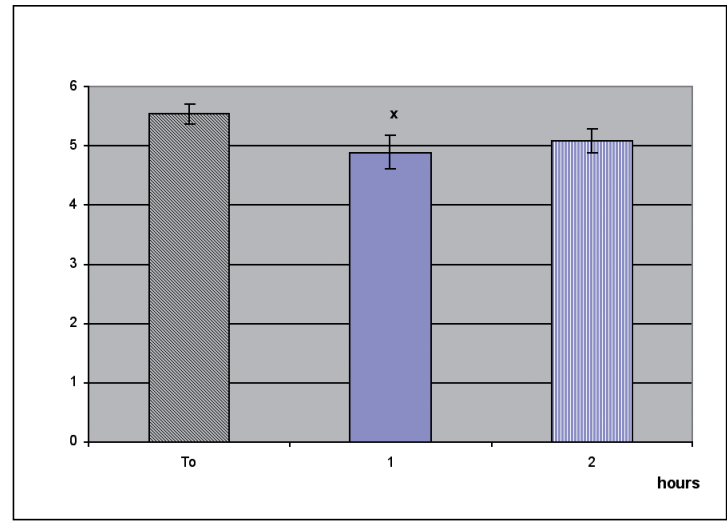

Fig. 2 a) The average $\mathrm{pH}$ of blood before the ethanol ingestion, 1 hour after ingestion and 2 hours after ingestion. Fig. 2 b) Average concentration of $\mathrm{pCO}_{2}$ before the ethanol ingestion, 1 hour after ingestion and 2 hours after ingestion. $\mathrm{x} \mathrm{p}<0.05$ compared with To (To $=$ initial value). 
Figure $2 \mathrm{~b}$ is the illustration of the $\mathrm{pCO}_{2}$ values in blood before the ingestion of ethanol $(5.51 \mathrm{kPa})$ and 1 and 2 hours after ingestion. We found that 1 hour after ingestion of alcohol the $\mathrm{pCO}_{2}$ was $4.89 \mathrm{kPa}$, therefore it significantly decreased by $0.62 \mathrm{kPa}(\mathrm{p}<0.05)$. After 2 hours, the $\mathrm{pCO}_{2}$ was $5.22 \mathrm{kPa}$ (NS to initial value).

Figure $3 \mathrm{a}$ is the comparison of the mean values of the base excesses in the blood before the ingestion of ethanol $\left(+1.53 \mathrm{mmol}^{-1} \mathrm{l}^{-}\right.$with values after 1 and 2 hours after ingestion. Base excess 1 hour after ingestion of ethanol significantly decreased to negative value -0.31 mmol. $\mathrm{l}^{-1}$, it means by $1.84 \mathrm{mmol}^{-1}$ ( $\left.\mathrm{p}<0.05\right)$. The decline continued even during $2^{\text {nd }}$ hour, when the BE was -0.48 mmol.1 ${ }^{-1}$; difference from initial value was significant $(\mathrm{p}<0.05)$ by $2.01 \mathrm{mmol} . \mathrm{l}^{-1}$. Since the normal range is taken as $0 \pm 3.0 \mathrm{mmol} . \mathrm{l}^{-1}$, the situation cannot be evaluated as a base deficiency (10).

Figure $3 \mathrm{~b}$ presents the mean values of the buffer base, which was after 1 hour decreased by $1.36 \mathrm{mmol}^{-1}$ (from $50.7 \mathrm{mmol}^{-1}$ to $49.32 \mathrm{mmol}^{-1}$ ) and after 2 hours by $8.16 \mathrm{mmol}^{-1}$ (from $50.7 \mathrm{mmol}^{\mathrm{l}^{-1}}$ to $42.54 \mathrm{mmol}^{-1}$ ). This decrease after 2 hours to the initial level was significant $(\mathrm{p}<0.01)$.

a

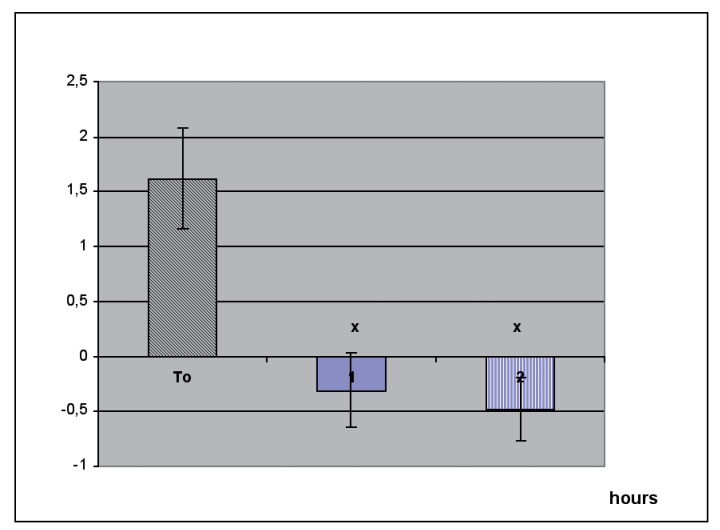

b

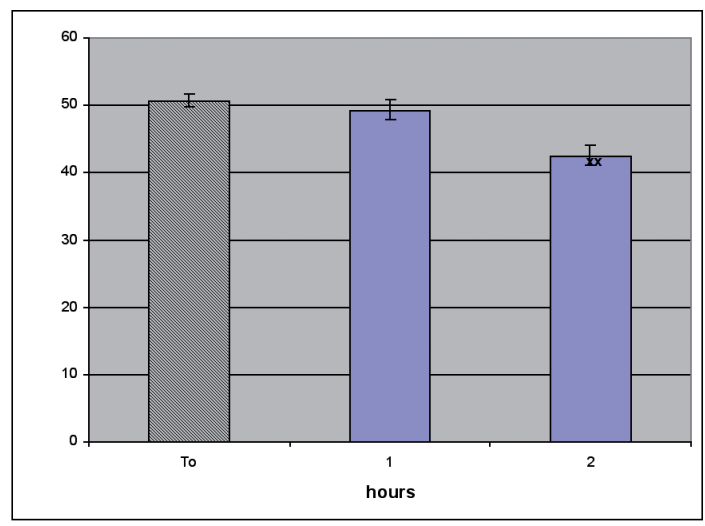

Fig. 3 a) The average value of excesses of bases in the blood before the ethanol ingestion, 1 hour after ingestion and 2 hours after ingestion. $\mathrm{x} p<0.05$ compared with initial value;

Fig. $3 \mathrm{~b}$ ) The average value of buffer base prior to ingestion of ethanol, 1 hour after ingestion and 2 hours after ingestion. $\mathrm{xx} p<0.01$ compared with initial value.

Figure 4a shows the values of standard $\mathrm{HCO}_{3}^{-}$, which fell after one hour by 1.58 mmol..$^{-1}$ (from $25.79 \mathrm{mmol}^{-1} \mathrm{l}^{-1}$ to $\left.24.21 \mathrm{mmol} \cdot \mathrm{l}^{-1} ; \mathrm{p}<0.05\right)$. After 2 hours the decline persisted $(24.0$ mmol.1.1-1).

In the Fig. $4 \mathrm{~b}$ are values of actual bicarbonate. This parameter was decreased significantly after 1 hour by $2.74 \mathrm{mmol.1} \mathrm{l}^{-1}$ (from $26.32 \mathrm{mmol.1-1}$ to $23.58 \mathrm{mmol}^{-1}-\mathrm{p}<0.01$ ). The decrease was found even after 2 hours, $23.79 \mathrm{mmol.}^{-1}$, however it was statistically non-significant $(\mathrm{p}=0.05)$. 
a

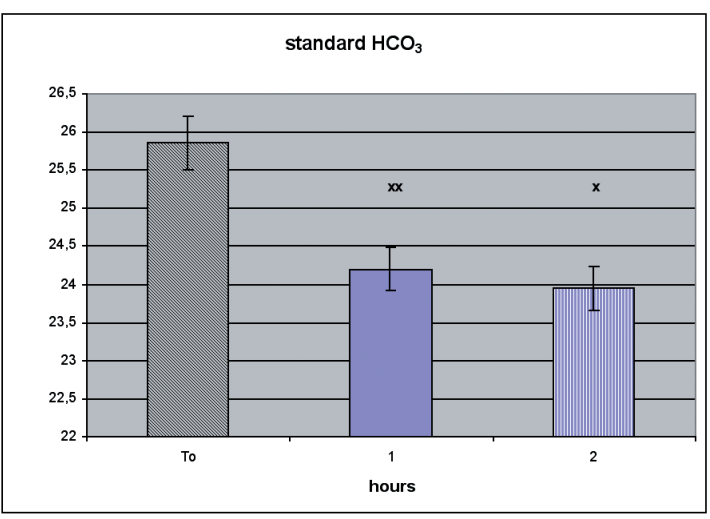

b

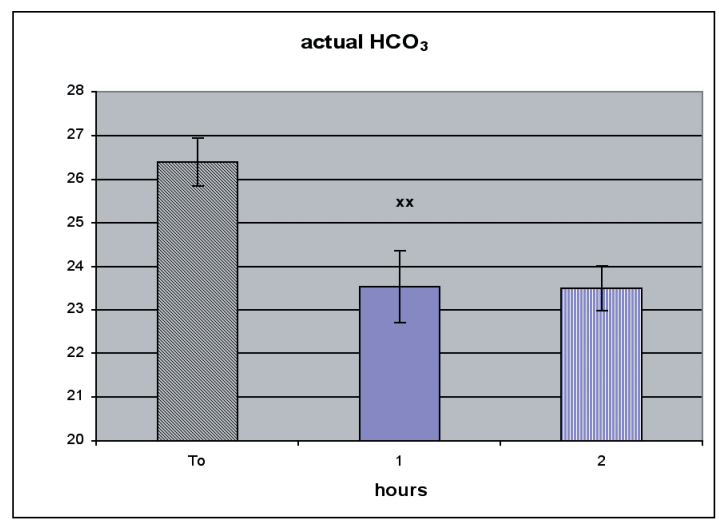

Fig. 4 a) Concentration of standard $\mathrm{HCO}_{3}{ }^{-}$in the blood before the ethanol ingestion, 1 hour after ingestion and 2 hours after ingestion. $\mathrm{x} \mathrm{p}<0.05 ; \mathrm{xx} \mathrm{p}<0.001$ compared with To;

Fig. 4 b) Concentration of actual bicarbonate in the blood before the ethanol ingestion, 1 hour after ingestion and 2 hours after ingestion; $x x \mathrm{p}<0.001$ compared with To (To $=$ initial value).

Before the ingestion of ethanol was the average glycaemia $4.89 \pm 0.22 \mathrm{mmol} / \mathrm{l}$, AST averages $0.23 \pm 0.02 \mathrm{ukat} / 1$, ALT averages $0.38 \pm 0.04 \mu \mathrm{kat} / 1$, GMT averages $0.21 \pm 0.04 \mu \mathrm{kat} / 1$, AMS averages $2.92 \pm 0.42 \mu \mathrm{kat} / 1$. All parameters were within the reference range (10). The shift of these values after ingestion of ethanol was not different from the initial values.

\section{DISCUSSION}

Alcohol metabolism is also influenced by various factors included genetic and racial ones (2, 14, 15 and others). Alcohol dehydrogenase and aldehyd dehydrogenase are enzymes that are present in several racial and genetic variations. Caucasian population breaks down alcohol faster than the Indians and Eskimos. In Japanese, Koreans and Thais is genetically determined an increased reactivity to small amounts of ethanol because they have different enzyme background for oxidation of ethanol. In our study group all probands were Caucasians.

We decided for Widmark method to determine concentrations of ethanol in blood, which is very laborious, but still accurate, most common in people who are alive (14). This method enables a more accurate determination of ethanol in blood in comparison with the determination using breath analyzers. Only $20.8 \%$ of the results of testing 610 cases from 11 workplaces in the Czech Republic and Slovakia using a respiratory analyzer tests correspond to the detected real alcohol level in blood (5).

In our group the input value of ethanol in blood was very slightly elevated. This can be explained by an early cup of juice or some confectionery products. Small quantities of alcohol are sometimes included in mouthwashes and certain toothpastes. Interestingly, the tolerability limits of blood alcohol concentration for drivers in EU are not yet uniform. Permissible concentration of alcohol in blood is usually $0.5 \mathrm{~g} . \mathrm{l}^{-1}$; in the Czech republic, in Romania and Hungary 0.0 g.1 $1^{-1}$; in Slovakia, Poland, Norway and Sweden 0.2 g. l $^{-1}$, in Great Britain, Ireland and Malta 0.8 g..$^{-1}$.

The amount of taken alcohol in young men in our group increased the concentration of ethanol in blood for a long time. The difference between the values of ethanol after 1 and 2 hours was not significant. We performed our testing on healthy probands. They were not exposed to physical exertion during the observation to avoid a possible effect of exercise on 
degradation of alcohol. We excluded disease states and drug effects that could slow down the degradation of ethanol in blood.

Hypoglycemia slows down absorption from stomach because it accelerates gastric emptying. Vice versa, hyperglycemia would slow down gastric emptying and thus accelerate the absorption from stomach $(3,14,19)$. Blood glucose concentration during our 2-hour observation did not change significantly.

In general, after ingestion of ethanol, the peak of its blood concentration is reached within 30-40 minutes. There is a subsequent fall which can be prolonged by e.g. slow oxidation in liver under absence of alcoholdehydrogenase, aldehyddehydrogenase, in chronic hepatitis of various genesis, during fasting or malnourishment, in chronic alcoholics or when MEOS activity is exhausted, etc. We monitored blood glucose, transaminases and amylase to try to exclude also the eventual hidden abnormalities in internal environment of probands to make sure that it did not affect the degradation of alcohol and ABB parameters. Straka et al. (2011) point out that small amounts of ingested alcohol can be eliminated from body even for 3 hours. The alcoholemic curve has a so called Grehant plateau (14). These protracted changes in acid-base balance could be an example of this phenomenon in our probands.

Food especially slows down the absorption of ethanol in stomach and small intestine. However, we did not expect a slower resorption of ethanol in our probands because they had had a light breakfast two hours before. We followed up peripheral acral circulation by using skin thermometer and digital reography on upper extremities. The probands were for two hours monitored in semihorizontal position and had no physical activity. That is why we cannot exclude whether this could not have delay the peak values of blood ethanol $(6,14)$. Although the arterial blood $\mathrm{pH}$ did not change significantly, our observation points out small but significant changes of some other values of $A B B$ affected by ethanol. The results vary in the distribution of normal values.

A relatively small intake of alcohol had an effect on base excess, possibly through an increase in lactate at the expense of pyruvate, as is the case with physical exertion. We have not yet benefited from the possibility of monitoring the lactate. Tendency to hypocapnia during one hour monitoring of $\mathrm{pCO}_{2}$ was not clinically associated with signs of pronounced hyperventilation. The probands were in a cheerful mood and partially logorrhoic, which could obscure a mild hyperventilation syndrome. We did not do measurement of ventilatory functions of lung. The aim of our work was not a closer monitoring of mental function after a single small dose of ethanol. In current literature the impact of ethanol on central and peripheral nervous system and other organs is often discussed $(2,9,12,13,14)$.

In outpatient clinical practice we sometimes meet patients who recently drunk a small amount of alcohol. Similarly, especially in traumatology, accidents often arise due to alcohol consumption. Low blood values of alcohol can be present in a patient who is admitted to a clinic for various unexpected acute conditions. The ABB values are assessed for essential diagnostics or its dynamics. In such cases it is not common to detect blood values of alcohol. The authors find important to document even "small" intake of alcohol which may be the cause of $\mathrm{ABB}$ shift to a pathological range. The doctors should always keep this in mind when doing the diagnostic statement.

\section{REFERENCES}

1. Buchancova, J., Buchanec, J., Hudeckova, H., Murajda, L., Hrivnak, I. Vplyv peroralne podaneho etanolu na digitalny reogram a telesnu teplotu. In: Szarazova, M., Kavcova, E., Janusova, T. editors. Podpora zdravia, prevencia a hygiena v teorii a praxi. VI. Martin: Beriss; 2009: 324-29.

2. Druesne-Pecollo, N., Tehard, B., Mallet, Y., Gerber, M., Norat, T., Hercberg, S., Latino-Martel, P. Alcohol and genetic polymorphisms: effect on risk of alcohol-related cancer. The Lancet Oncology 2009; 10(2): 173-180.

3. Dzurik, R. a kol. Poruchy vnutorneho prostredia. Diagnostika a terapia. Martin: Osveta; 1994.

4. Harbison, RD.: Industrial toxicology. St.Louis: Mosby; 1998. 
5. Hirt, M., Vojtisek, T., Zeleny, et al. The correlation of results of breath analysers and laboratory blood examinations of blood-ethanol concentration (Czech and Slovak study) Soud.Lek 2010; 55(1): 8 - 9.

6. Javorka, K. a kol.: Lekarska fyziologia. III ed. Martin: Osveta; 2009.

7. Koval, J., Havrilla, R., Kordovanova, J., Balaz, J.: Intoxikacia alkoholom - novodoby trend mladeze. Pediatria 2007; 2(6): 333-8.

8. Kresanek, J. Drogova zavislost, interakcia s faktormi prace a pracovneho prostredia. In: Buchancova a spol. Pracovne lekarstvo a toxikologia. Martin: Osveta; 2003: 967-974.

9. Kunda, S. Klinika alkoholizmu. Martin, Osveta, 1988.

10. Mesko, D.,Pullman, R., Nosalova,G. Vademekum klinickej biochemie. Martin: Osveta; 1998.

11. Neuman,GM. Cytokines - central factors in alcoholic liver diesase. Alcohol Res.Health, $2003 ; 27$ (4):307-316.

12. Nociar, A. Alkohol, drogy a osobnost. Bratislava Asklepios; 2001.

13. Schuckit, MA. Alcohol-use disorders. The Lancet 2009; 373(9662):492-501.

14. Straka, L., Novomesky, F., Krajcovic, J., Stuller, F. Sudnolekarska alkohologia. Martin: Osveta; 2011.

15. Turecky, L. Biochemia a patobiochemia etanolu. Lek.Obz 2008; 56 (6): 241-254.

16. Worrall,S, Jersey,DJ,Nicholls,R, Wilce,PA. Acetaldehyde/ protein interactions:are they involved in the pathogenesis of alcoholic liver disease? Dig Dis 1993; 11: 265 -271.

17. Zima, M. Alkoholova hepatitida. Etiopatogeneza a klinicke aspekty. Lek Obz 2008; 56 (6): $255-258$.

18. Zima, T.: Alkohol. Cas. Lek. Ces. 1996; 135(4):458-465.

19. Zering,G.,Saria,A.,Kurz,M, O Malley,S.S. Handbook of alcoholism. Boca Raton CRC Press,LLC,2000, 207 p.

Received: July,1, 2011

Accepted: March, 17, 2012 